\title{
The Role of Current Banking System in the Growth of Industrial Sector in Isfahan Province (Iran)
}

\author{
Hamid Abrishami ${ }^{\mathrm{a}}$, Masoud Saboji ${ }^{* b}$ \\ Faculty of Economics, University of Tehran, Tehran, Iran \\ E-mail address: aabrishami_hamid@yahoo.com, 'bmasoud_saboji@alumni.ut.ac.ir
}

Keywords: Value added; Panel data; Industrial, Agriculture and Services sectors; specialized and commercial banks

\begin{abstract}
Studying the function of banks is crucial because their vigorous role in the economy seems to be a subject of immense importance. In the present study, we analyze and study the role of whole banks, commercial banks and specialized banks between 2002 and 2012 in Isfahan, based on the growth of value added approach in the industrial sector. In order to investigate this matter, we have estimated three extinction panels for the whole banking system, specialized banks and commercial banks in Eviews 9.

Based on the results it can be argued that in the panels of whole banks and specialized banks, payment facilities have a positive and meaningful impact on the growth of value added in all three sectors of the economy, but in the panel of commercial banks, only banking facilities on a 10 percent level have a positive and meaningful impact on the growth of value added in the industrial sector. As a result, we can conclude that specializing the bank's activities can have a positive effect on the growth of value added in various sectors of the economy.
\end{abstract}

\section{Introduction}

Some previous economists (Schumpeter, 1912; McKinnon, 1973) frequently emphasize the roles of the financial system in economic development [1, 2]. The connection between financial development and economic growth has gotten much consideration in new years [3], for example, Schumpeter used the link between banker and industrialist to show the significance of the financial system in selecting and adopting new applied sciences [1]. So, there are various opinions regarding the role that the financial system performs in the growth of economies [3].

For instance, while Levine (1997) and Diamond (1984) believe that financial intermediaries improve economic efficiency by decreasing monitoring costs, and finally growth, by helping allocate capital to its best uses, Lucas (1988) declares that the role of the financial sector in economic growth is "overemphasized" [3-5].

The main duty of the financial system is to make easy the allocation and strategic positioning of economic resources, both across time and spatially, in an unsure environment. This system comprises of the primary payment system through which practically all business deal obvious and the capital markets, which include the money, equity, fixed-income, options markets, and futures and financial intermediaries. The capital markets are the channel that makes possible the basic cashflow cycle of household savings flowing to capital investments by firms, followed by a return to households for consumption and recycling as new savings [6]. In between, the link between economic growth and financial development has been a great subject, specifically in the industrial sector. The financial sector manages an increase promoting role if it is able to direct financial resources towards the sectors that demand those most. The more the financial sector is improved, the more financial resources can be allotted into productive use, and more physical capital formed which can contribute impressively to economic growth [7].

Comprehending the many roles that banks perform in the financial system is one of the fundamental subjects in theoretical economics and finance [8]. The investigation by Odedokun (1992), Khan and Luintel (1999), and favor bidirectional causality between finance and growth. Both economic and financial expansions are causally pertained where financial development causes economies to grow 
and economic growth causes financial sector to develop further [9]. The proficiency of the procedures through which savings are channeled into productive activities is critical for growth and general welfare. Banks are one part of this procedure. Fig 1 gives an overview of the functioning of a financial system.

Lenders of cash are primarily households and firms. These lenders can allocate money to the final borrowers, who are chiefly households, firms and governments, in two ways. The first is through financial markets, which comprise of money markets, equity markets and bond markets. The second is using banks and other financial mediators such as money market funds, insurance companies, pension funds and mutual funds [8]. It has been shown that banks have a significant part in the process of financial progress and the development of the economy as a whole [10].

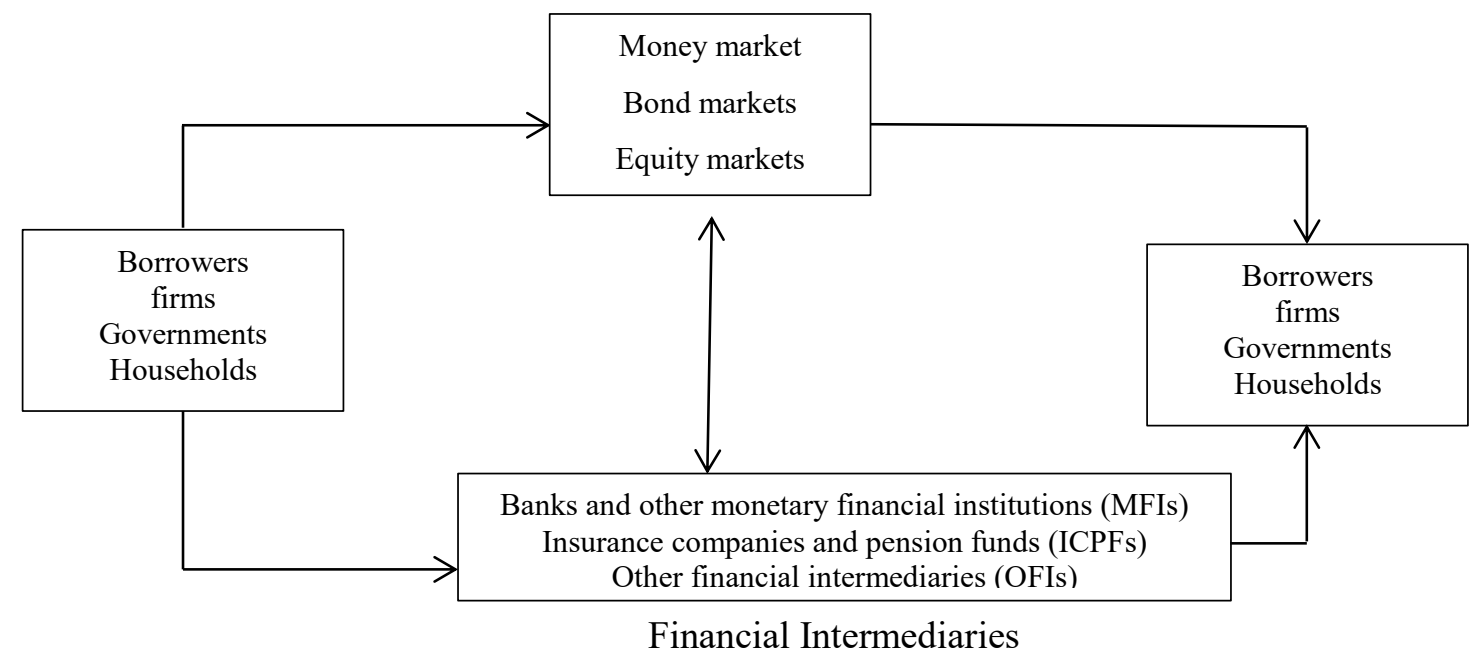

Figure 1: An overview of the financial system [8]

In this study, the industrial sector plays an essential role in the growth of economies regarding a prominent case that it is considered. To continue production and investment in the sector, investors and manufacturers need to have the funds according to investment costs and raw materials that a strong financial base is very significant. However, the monetary system and financial performance of the major systems in any economy, the performance of the system returns to deal its components: commercial banks and specialized financial institutions, corporations, government and households.

\section{Methodology and empirical results}

The first merit of transporting to a panel is the ability to take advantage of the time-series and crosssectional variation in the data. The second advantage is that it prevents biases associated with crosssectional regressions by taking the specific fixed effect into consideration [11]. Therefore, in this study, we use the Panel Data models to evaluate the effect of credit whole banks in the growth of the industrial sector. The advantage of panel data from the perspective of Greene (1997) can be more flexible in modeling different behaviors value-added function [12].

Also, in this study the variables related to the industry and mining, including the facilities granted by banks, labor employed in industry and mining sector and the growth of value added industry. These variables are obtained annually (2002 to 2012), as cross-sectional variables, from the Statistical Center of Iran (SCI).

Therefore, to show the role of the banking system of the province of Isfahan in the growth of different sectors of the production was used the function as follows [13]:

$$
Y_{i t}=\beta_{0}+\beta_{1} X_{2 i t}+\beta_{2} X_{2 i t}+\beta_{3} X_{3 i t}+u_{i t} .
$$

Where the variable $\mathrm{Y}$ is the value added in terms of current prices for the period $\mathrm{i}$ in year $\mathrm{t}$ (province GDP), this variable as the best indicator to show the size and scale of the market (size of the economy) and it is expected that large scale economies, provide better conditions for foreign investors (Thomas, 1999). 
Variable $\mathrm{X}_{1}$, employment in the province related to the section $\mathrm{i}$ in year $\mathrm{t}$ and $\mathrm{X}_{2}$ variable $\mathrm{i}$ in year $\mathrm{t}$, banking facilities in section $i$ and in year $t$ is an alternative to variable capital in the production of the province.

The relationship provides estimates for each of the sectors is as follows; the only difference that in each condition facility variables, once refers to the total loan, once the facilities of commercial banks and once the facilities of specialized banks. To calculate value added by each sector, formula (1) is rewritten in the form of formula (2). The relationship provides estimates for each of the sectors is as follows;

$$
Y_{i t}=C_{i}+\beta_{1} L X 11+\beta_{1} L X 12+\beta_{1} L X 13+\beta_{1} L X 21+\beta_{1} L X 22+\beta_{1} L X 23+\varepsilon_{i t} .
$$

Where:

LX11: logarithm of employment in industrial sector

LX12: logarithm of employment in the agriculture sector

LX13: logarithm of employment in the Service sector

LX21: logarithm of the total facilities of the banking system in the industry sector

LX22: logarithm of the total facilities of the banking system in the agricultural sector

LX23: logarithm of the total facilities of the banking system in the service sector

2.1 Reviews stationary variables. In the following to prevent the problem of spurious regression model to study the stationary variables analyzed. Results of data in the stationary (with intercept and trend) based on the statistic Levin, Lin \& Chu are presented in Table 1.

Table 1: Analysis stationary variables of the model

\begin{tabular}{|c|c|c|c|c|}
\hline Name of variable & $\begin{array}{c}\text { Abbreviation } \\
\text { variable }\end{array}$ & $\begin{array}{c}\text { Statistic } \\
\text { value }\end{array}$ & $\begin{array}{c}\text { Level of } \\
\text { significance }\end{array}$ & Result \\
\hline logarithm Value added & Y & 2.08 & 5 percent & $\begin{array}{c}\text { The variable is } \\
\text { stationed }\end{array}$ \\
\hline $\begin{array}{c}\text { logarithm Employment } \\
\text { in industrial sector }\end{array}$ & LX11 & -4.08 & 1 Percent & $\begin{array}{c}\text { The variable is } \\
\text { stationed }\end{array}$ \\
\hline $\begin{array}{c}\text { logarithm Employment } \\
\text { in the agriculture sector }\end{array}$ & LX12 & -6.71 & 1 Percent & $\begin{array}{c}\text { The variable is } \\
\text { stationed }\end{array}$ \\
\hline $\begin{array}{c}\text { logarithm Employment } \\
\text { in the Service sector }\end{array}$ & LX13 & -5.13 & 1 Percent & $\begin{array}{c}\text { The variable is } \\
\text { stationed }\end{array}$ \\
\hline $\begin{array}{c}\text { logarithm Facilities of } \\
\text { entire banking system }\end{array}$ & LX21 & -7.48 & 1 Percent & $\begin{array}{c}\text { The variable is } \\
\text { stationed }\end{array}$ \\
\hline $\begin{array}{c}\text { logarithm Facilities of } \\
\text { commercial banks }\end{array}$ & LX22 & -2.73 & 1 Percent & $\begin{array}{c}\text { The variable is } \\
\text { stationed }\end{array}$ \\
\hline $\begin{array}{c}\text { logarithm Facilities of } \\
\text { specialized banks }\end{array}$ & LX23 & -4.82 & 1 Percent & $\begin{array}{c}\text { The variable is } \\
\text { stationed }\end{array}$ \\
\hline
\end{tabular}

Source: research findings

2.2 Select the estimated model in the mode of payment facilities of the entire banking system. To determine the optimal model among the three methods of common effect, the effect of fixed and random on the models of Panel used Hausman and F-Leamer tests. Statistics F-Leamer and Hausman tests the entire banking system payments facility Panel in table 2:

Table 2: Log likelihood ratio test fixed effects and Hausman test in the modality of the payment facility of the entire banking system

\begin{tabular}{|c|c|c|c|c|c|}
\hline Test & $\begin{array}{c}\text { Statistic } \\
\text { value }\end{array}$ & $\begin{array}{c}\text { Degrees of } \\
\text { freedom }\end{array}$ & $\begin{array}{c}\text { The value of } \\
\text { statistics }\end{array}$ & $\begin{array}{c}\text { Level of } \\
\text { significance }\end{array}$ & The result of the test \\
\hline $\begin{array}{c}\text { F-Leamer } \\
\text { test }\end{array}$ & $\mathrm{F}$ & $(2,15)$ & 7.67 & 0.019 & The null hypothesis is rejected \\
\hline $\begin{array}{c}\text { Hausman } \\
\text { test }\end{array}$ & $\begin{array}{c}\text { Chi } \\
\text { square }\end{array}$ & 2 & 7.67 & 0.0049 & The null hypothesis is rejected \\
\hline
\end{tabular}


The null hypothesis in the F-Leamer test is as follows:

$\mathrm{H}_{0}$ : The parameters of the width of the source in all divisions (sections) are equal

$\mathrm{H}_{1}$ : The parameters of the width of the source in all divisions (sections) are not equal

In regards to the null hypothesis, F-Leamer test has been rejected, the fixed effects of estimation methods have been prioritized over model-based estimate of the joint effects. The result has necessarily been chosen among a fixed effects method and one randomly now. The Hausman test is used to choose between these two methods. If $\hat{\beta}_{O L S}$ is the indicator of estimators of fixed effects method and $\hat{\beta}_{G L S}$ show the estimators of random effect, then, unlike fixed effect model, $\mu \mathrm{i}$ and xi are not correlated and are independent of each other in random effect model. Since $\mu$ is are placed in the error sentence, thus, E(uit/xit) is assumed to equal zero and the null hypothesis in this test is presented as below:

$\mathrm{H}_{0}$ : plimq $=\operatorname{plim}\left(\beta_{\mathrm{FE}}-\beta_{\mathrm{GLS}}\right)=$ the random effect method is more efficient.

$\mathrm{H}_{1}$ : plimq $\neq$ plim $\left(\beta_{\mathrm{F} . \mathrm{E}}-\beta_{\mathrm{GLS}}\right)=$ the fixed effect method is more efficient.

In the science of econometrics, the limit of the probabilities function is expressed through plim. This limit indicates a point in the distribution function in which increasing the volume of the sample results to a change in the shape of the distribution function.

If by doing Hausman test in Eviews software, Prob be less than 0.1, fixed effect of model is accepted above 90 percent but if it be greater than 0.1 then random effect is accepted.

According to the results in Table 2, null hypotheses skips, therefore estimates of the fixed effects are more efficient than the random effects. Then, the estimated fixed effects model will be discussed below.

Table 3: The results of the estimation of the Panel data in fixed effects mood in the model entire banking system payments facility

\begin{tabular}{|ccccc|}
\hline Variable & Coefficient & $\begin{array}{c}\text { Standard } \\
\text { deviation }\end{array}$ & T-statistic & $\begin{array}{c}\text { Level of } \\
\text { significance }\end{array}$ \\
\hline \hline C & 9.145656 & 4.017110 & 2.054966 & 0.0460 \\
1--LX11 & 0.938561 & 0.069098 & 13.58311 & 0.0000 \\
2--LX12 & 0.966205 & 0.215088 & 4.492140 & 0.0003 \\
3--LX13 & 0.839685 & 0.152635 & 5.501268 & 0.0000 \\
1--LX21 & 1.106797 & 0.111767 & 9.902680 & 0.0000 \\
2--LX22 & 0.807469 & 0.216881 & 3.723099 & 0.0020 \\
3--LX23 & 0.745912 & 0.152711 & 4.884468 & 0.0002 \\
Fixed Effects (Cross) & 11.62960 & & & \\
1-C & 17.12615 & & & \\
2-C & -28.75575 & & & \\
3-C & Effects Specification & \\
\hline \hline \multicolumn{5}{c}{ Cross-section fixed (dummy variables) } \\
\hline \hline \multicolumn{5}{c}{ Weighted Statistics } \\
\hline \hline R-squared & 0.990300 & Mean dependent var & 19.83166 \\
Adjusted R-squared & 0.985126 & S.D. Dependent var & 8.598173 \\
S.E. Of regression & 0.179253 & Sum squared resid & 0.481972 \\
F-statistic & 191.4151 & Durbin-Watson stat & 2.658063 \\
Prob (F-statistic) & 0.000000 & & \\
\hline \hline & & & \\
\hline \hline
\end{tabular}

Source: research findings 
According to the results of the estimation model of panel data in fixed effects mood is achieved the following results:

1. Employment in all three sections have a meaningful and positive impact on the growth of value added economy. In such a way, the employment has impacted on the growth of value added of industry $(0.93 \%)$; value added of agricultural $(0.96 \%)$ and value added of services $(0.83 \%)$. The comparison of estimated coefficients showed which employment in the agricultural sector had more effect than other categories. Considering that the variables have been entered into on the basis of the logarithm, the added value of the different parts than labor force low elastic can be assessed.

2. Banking facilities in any three sections have meaningful and positive impact on the value added economy. In such a way the banking facility has an impact on the value added of industry (1.1\%); agricultural added value $(0.8 \%)$ and services added value $(0.74 \%)$. Based on comparison of estimated coefficients can be observed that the banking facilities on the part of the industry has influence over other parts. Considering that the variables have been entered based on the logarithm, the value added of industrial sector proved more elastic than the facilities and the added value of agricultural and services sectors evaluate less elastic than payments facilities evaluation. More elastic being industry sector than the facilities can be rooted in the low volume, liquidity and have high need this sector to the banking facilities. Based on the results of the research center of Central Bank, industrial sector finance more than 45 percent of its funds through the banking system.

3 . In the industry sector, the most important variable in the value added of this sector; according to the magnitude of the estimated coefficient and a significant level of employment and credit; but in the agricultural and services sectors, the opposite occurred of this mood.

4. Based on the results table above, 1-C, 2-C and 3-C, respectively, the width of altitude origins industry, agriculture and services. The width of the source model represents the characteristics and features of the Bank under investigation is not in terms of the model.

2.3 Select the estimated model in the mode of payment facilities of the commercial Bank. To determine the optimal model among the three methods of common effect, the effect of fixed and random effects in the models of panel data used Hausman and F-Leamer tests. Commercial banks panel F-Leamer and Hausman statistics are provided in table 4.

Table 4: The Likelihood fixed effects and Hausman test in the modality of the payment facilities of commercial bank

\begin{tabular}{|c|c|c|c|c|c|}
\hline Test & $\begin{array}{c}\text { Statistic } \\
\text { value }\end{array}$ & $\begin{array}{c}\text { Degrees of } \\
\text { freedom }\end{array}$ & $\begin{array}{c}\text { The value of } \\
\text { statistics }\end{array}$ & $\begin{array}{c}\text { Level of } \\
\text { significance }\end{array}$ & The result of the test \\
\hline $\begin{array}{c}\text { F-Leamer } \\
\text { test }\end{array}$ & $\mathrm{F}$ & $(2,15)$ & 6.05 & 0.0427 & $\begin{array}{c}\text { The null hypothesis is } \\
\text { rejected }\end{array}$ \\
\hline $\begin{array}{c}\text { Hausman } \\
\text { test }\end{array}$ & Chi square & 2 & 8.39 & 0.0025 & $\begin{array}{c}\text { The null hypothesis is } \\
\text { rejected }\end{array}$ \\
\hline
\end{tabular}

Source: research findings

The null hypothesis in the F-Leamer test is as follows:

$\mathrm{H}_{0}$ : The parameters of the width of the source in all divisions (sections) are equal

$\mathrm{H}_{1}$ : The parameters of the width of the source in all divisions (sections) are not equal

In regards to the null hypothesis F-Leamer test has been rejected, the fixed effects of estimation method have been prioritized than model-based estimate of the joint effects. According to the results of table 4, null hypothesis is able to reject, As a result, estimates in the case of fixed effects is more efficient than the random effects. Then, estimate model in the state of fixed effects will be discussed in the table below: 
Table 5: The results of the estimation of the Panel data in fixed effects mood in the model payment facilities by commercial banks

\begin{tabular}{|ccccc|}
\hline Variable & Coefficient & $\begin{array}{c}\text { Standard } \\
\text { deviation }\end{array}$ & T-statistic & $\begin{array}{c}\text { Level of } \\
\text { significance }\end{array}$ \\
\hline \hline C & -18.50964 & 12.47467 & -1.483778 & 0.1586 \\
1--LX11 & 1.223652 & 0.076822 & 15.92850 & 0.0000 \\
2--LX12 & 0.992256 & 0.128676 & 7.711281 & 0.0000 \\
3--LX13 & 0.745912 & 0.113327 & 6.581944 & 0.0000 \\
1--LX21 & -1.016324 & 0.594558 & -1.709377 & 0.1080 \\
2--LX22 & 2.709051 & 0.925595 & 2.926821 & 0.0104 \\
3--LX23 & 3.045947 & 2.615163 & 1.164725 & 0.2623 \\
Fixed Effects (Cross) & 30.31820 & & & \\
1-C & -10.92643 & & & \\
2-C & -19.39177 & & \\
3-C & Effects Specification & \\
\hline \hline \multicolumn{5}{c}{ Cross-section fixed (dummy variables) } \\
\hline \hline \multicolumn{5}{c}{ Weighted Statistics } \\
\hline \hline R-squared & 0.989501 & Mean dependent var & 18.79543 \\
Adjusted R-squared & 0.983902 & S.D. Dependent var & 5.581906 \\
S.E. Of regression & 0.166783 & Sum squared resid & 0.417250 \\
F-statistic & 176.7144 & Durbin-Watson stat & 2.446552 \\
Prob (F-statistic) & 0.000000 & & \\
\hline \hline \multicolumn{5}{c}{ Solut } \\
\hline \hline
\end{tabular}

Source: research findings

According to the results of the estimation model of panel data in fixed effects mood achieved the following results:

1. Employment in all three sections has meaningful and positive impact on the growth of value added economy. In such a way that the employment on the growth of value added of industry $(1.22 \%)$; agriculture $(0.99 \%)$ and services $(0.74 \%)$ have impacted.

2. Payment facilities of commercial bank only in the agricultural sector have meaningful and positive impact on the growth of value added economy. In such a way that the Payment facilities have an impact on the growth of value added of industry and services by banks.

3. In the panel above, Employment variable in industry and services sectors, had the most effect on the growth of value added, But the opposite had occurred in agriculture sector.

2.4 Select the estimated model in the mode of payment facilities of the specialized Bank. To determine the optimal model among the three methods, of common effect, the effect of fixed and random effects in the models of Panel data used Hausman and F-Leamer tests. Specialized banks panel F-Leamer and Hausman statistics are provided in table 6.

Table 6: Likelihood fixed effects and Hausman test in the modality of the payment facility specialized bank

\begin{tabular}{|c|c|c|c|c|c|}
\hline Test & $\begin{array}{c}\text { Statistic } \\
\text { value }\end{array}$ & $\begin{array}{c}\text { Degrees of } \\
\text { freedom }\end{array}$ & $\begin{array}{c}\text { The value of } \\
\text { statistics }\end{array}$ & $\begin{array}{c}\text { Level of } \\
\text { significance }\end{array}$ & The result of the test \\
\hline $\begin{array}{c}\text { F-Leamer } \\
\text { test }\end{array}$ & $\mathrm{F}$ & $(2,15)$ & 17.67 & 0.0001 & $\begin{array}{c}\text { The null hypothesis is } \\
\text { rejected }\end{array}$ \\
\hline $\begin{array}{c}\text { Hausman } \\
\text { test }\end{array}$ & Chi square & 2 & 19.13 & 0.0000 & $\begin{array}{c}\text { The null hypothesis is } \\
\text { rejected }\end{array}$ \\
\hline
\end{tabular}


The null hypothesis in the F-Leamer test is as follows:

$\mathrm{H}_{0}$ : The parameters of the width of the source in all divisions (sections) are equal

$\mathrm{H}_{1}$ : The parameters of the width of the source in all divisions (sections) are not equal

As regards the null hypothesis F-Leamer test has been rejected, the fixed effects of estimation method have been prioritized than model-based estimate of the joint effects. According to the results of table 6, null hypothesis is able to reject, As a result, estimates in the case of fixed effects is more efficient than the random effects. Then, estimate model in the state of fixed effects will be discussed.

According to the results of the estimation model of panel data in fixed effects mood achieved the following results:

1. Employment in all three sections has a meaningful and positive impact on the growth of value added economy. In such a way that the employment on the growth of value added of industry $(1.45 \%)$; agriculture $(1.87 \%)$ and services $(0.01 \%)$ have impacted.

2. Facilities of specialized bank in any three sections have meaningful and positive impact on the growth of value added economy. In such a way that the banking facilities have an impact on the growth of value added of industry (6.8\%); agriculture (4.27\%) and services (14.92\%). According to the results table 7 you can see that in the case of specialized banks, facilities of the banking system's impact on economic growth has risen sharply.

3. In the above panel in each of three sections industry, agriculture and services, payment facilities variable had the most impact on the added value, by specialized banks.

Table 7: The results of the estimation of the Panel data in fixed effects mood in the model payment facilities by specialized banks

\begin{tabular}{|c|c|c|c|c|}
\hline Variable & Coefficient & $\begin{array}{l}\text { Standard } \\
\text { deviation }\end{array}$ & T-statistic & $\begin{array}{c}\text { Level of } \\
\text { significance }\end{array}$ \\
\hline $\begin{array}{c}\text { C } \\
\text { 1--LX11 } \\
\text { 2--LX12 } \\
\text { 3--LX13 } \\
\text { 1--LX21 } \\
\text { 2--LX22 } \\
\text { 3--LX23 } \\
\text { Fixed Effects (Cross) } \\
\text { 1-C } \\
\text { 2-C } \\
3-\mathrm{C}\end{array}$ & $\begin{array}{l}3.966672 \\
1.452895 \\
1.879961 \\
0.009444 \\
6.808083 \\
4.273138 \\
14.92330 \\
\\
6.752513 \\
14.90724 \\
-21.65975\end{array}$ & $\begin{array}{l}1.758738 \\
0.139936 \\
0.102038 \\
0.004152 \\
0.818282 \\
0.620937 \\
0.083823\end{array}$ & $\begin{array}{l}2.255408 \\
10.38253 \\
18.42407 \\
2.274266 \\
8.319967 \\
6.881755 \\
178.0341\end{array}$ & $\begin{array}{l}0.0395 \\
0.0000 \\
0.0000 \\
0.0362 \\
0.0000 \\
0.0000 \\
0.0000\end{array}$ \\
\hline \multicolumn{5}{|c|}{ Effects Specification } \\
\hline \multicolumn{5}{|c|}{ Cross-section fixed (dummy variables) } \\
\hline \multicolumn{5}{|c|}{ Weighted Statistics } \\
\hline $\begin{array}{c}\text { R-squared } \\
\text { Adjusted R-squared } \\
\text { S.E. Of regression } \\
\text { F-statistic } \\
\text { Prob (F-statistic) }\end{array}$ & $\begin{array}{l}0.999697 \\
0.999536 \\
0.206882 \\
6189.923 \\
0.000000\end{array}$ & $\begin{array}{c}\text { Mean dep } \\
\text { S.D. Dep } \\
\text { Sum squ } \\
\text { Durbin-W }\end{array}$ & $\begin{array}{l}\text { ndent var } \\
\text { ndent var } \\
\text { red resid } \\
\text { atson stat }\end{array}$ & $\begin{array}{l}192.8487 \\
258.1157 \\
0.642004 \\
1.695556\end{array}$ \\
\hline \multicolumn{5}{|c|}{ Unweighted Statistics } \\
\hline $\begin{array}{c}\text { R-squared } \\
\text { Sum squared resid }\end{array}$ & $\begin{array}{l}0.983701 \\
0.642004\end{array}$ & $\begin{array}{l}\text { Mean dep } \\
\text { Durbin-W }\end{array}$ & $\begin{array}{l}\text { endent var } \\
\text { atson stat }\end{array}$ & $\begin{array}{l}16.66196 \\
1.839510\end{array}$ \\
\hline
\end{tabular}

Source: research findings 


\section{Conclusions and suggestions}

The study of performances of banks is very important due to their key role in economy. According to Levin (1997) Theory, the fundamental role of banks in national economy is a vital variable in the process of financial development and economic growth. Thus, the present study investigated the role of banks of Isfahan Province in value added and employment in industry, service and agriculture sectors in the period between 2002 and 2012.

The results of the study showed that:

Studying the function of banks is important due to their vital role in economy seems to be an issue of immense importance. As Levine (1997) points out, banks have an important role in the process of financial progress and the development of economy as a whole.

Based on the findings of the study were:

The employment impacted on the growth of value added of industry $(0.93 \%)$; agriculture $(0.96 \%)$ and services $(0.83 \%)$.

The banking facilities have an impact on the growth of value added of industry $(1.1 \%)$; agricultural $(0.8 \%)$ and services $(0.74 \%)$.

Based on the results obtained with respect to the coefficients of accepting or rejecting hypotheses are as follows:

- Due to the model estimation Table 3, which shows the model in general because variable coefficient employment by the banking system was positive and significant on all three sections, in conclusion, hypothesis one, said that "employment of entire banks has a positive impact on the growth of value added in several divisions" was. According to the sample obtained and the time period studied there was no reason to reject this hypothesis.

Regarding the positive significant effect of facilities of the entire banking system on value added of various sectors, it is suggested to establish banks in Iran with perspectives based on Profit Loss Sharing Approach. The spread of such banks and specialization of banks can decrease the level of deferred debts of the banking system, and increase employment and economic value added.

\section{References}

[1] J. A. Schumpeter, O. Redvers, Theorie der wirtschaftlichen Entwicklung. The Theory of Economic Development. An inquiry into profits, capital, credit, interest, and the business cycle... Translated... by Redvers Opie, Transaction Publishers, New brunswick (U.S.A.) and London (U.K.), 1934.

[2] R. I. McKinnon, Money and capital in economic development, Brookings Institution Press, Washington, D.C., 1973.

[3] R. Levine, Financial development and economic growth: views and agenda, J. Econ. Lit. 35 (2) (1997) 688-726.

[4] D. W. Diamond, Financial intermediation and delegated monitoring, Rev. Econ. Stud. 51 (3) (1984) 393-414.

[5] R. E. Lucas, On the mechanics of economic development, J. Monetary. Econ. 22 (1) (1988) 342 .

[6] R. C. Merton, The financial system and economic performance, Springer, 1990.

[7] H. Furqani, R. Mulyany, Islamic banking and economic growth: Empirical evidence from Malaysia, J. Econ. Co. Dev. 30 (2) (2009) 59-74.

[8] A. Franklin, E. Carletti, The Roles of Banks in Financial Systems, A Berger, P Molyneux \& J Wilson (Eds), Oxford Handbook of Banking. 2008. 
[9] M. O. Odedokun, Supply-leading and demand-following relationship between economic activities and development banking in developing countries: an international evidence, Singapore. Econ. Rev. 37 (1992) 46-58.

[10]R. G. King, R. Levine, Finance and growth: Schumpeter might be right, The quarterly journal of economics. (1993) 717-737.

[11]R. Levine, Finance and growth: theory and evidence, Handbook of economic growth. 1 (2005) 865-934.

[12]W. Green, Econometric Analysis,third ed. Upper Saddle River, NJ.: Prentice-Hall, 1997.

[13]D. N. Gujarati, Basic Econometrics, forth ed, McGraw-Hill, New York, 2003. 